\title{
Volatile Organic Compounds (VOCs) Emitted from Coated Furniture Units
}

\author{
Ozge Cemiloglu Ulker ${ }^{1}$, Onur Ulker ${ }^{2, *}$ and Salim Hiziroglu ${ }^{3} \mathbb{D}$ \\ 1 Department of Toxicology, Faculty of Pharmacy, Ankara University, Ankara 06560, Turkey; \\ oulker@pharmacy.ankara.edu.tr \\ 2 Department of Interior Architecture, Faculty of Architecture and Design, Eskisehir Technical University, \\ Eskisehir 26555, Turkey \\ 3 Department of Natural Resource Ecology and Management, Ferguson College of Agriculture, \\ Oklahoma State University, Stillwater, OK 74078, USA; salim.hiziroglu@okstate.edu \\ * Correspondence: onurulker@eskisehir.edu.tr
}

Citation: Ulker, O.C.; Ulker, O.; Hiziroglu, S. Volatile Organic Compounds (VOCs) Emitted from Coated Furniture Units. Coatings 2021, 11, 806. https://doi.org/10.3390/ coatings11070806

Academic Editor: Benedetto Pizzo

Received: 6 June 2021

Accepted: 29 June 2021

Published: 2 July 2021

Publisher's Note: MDPI stays neutral with regard to jurisdictional claims in published maps and institutional affiliations.

Copyright: (C) 2021 by the authors. Licensee MDPI, Basel, Switzerland. This article is an open access article distributed under the terms and conditions of the Creative Commons Attribution (CC BY) license (https:// creativecommons.org/licenses/by/ $4.0 /)$.

\begin{abstract}
Volatile organic compounds (VOCs) are the main source influencing the overall air quality of an environment. It is a well-known fact that coated furniture units, in the form of paints and varnishes, emit VOCs, reducing the air quality and resulting in significant health problems. Exposure time to such compounds is also an important parameter regarding their possible health effects. Such issues also have a greater influence when the exposure period is extended. The main objective of this study was to review some of the important factors for the emission of VOCs from coated furniture, from the perspective of material characteristics, as well as health concerns. Some methods for controlling VOC emissions to improve indoor air quality, from the point of view recent regulations and suggestions, are also presented in this work.
\end{abstract}

Keywords: volatile organic compounds (VOCs); air quality; adverse health effects; furniture units; wood-based panels

\section{Introduction}

Volatile organic compounds (VOCs) are widely emitted from furniture units coated with paints, varnishes, waxes, and solvents [1-4]. It was determined that solid wood and wood composite-based furniture units play an important role in VOC emission, influencing overall indoor air quality [5]. Emission compounds, testing methods for identifying such compounds, and their cumulative effects on environmental factors are key factors for determining limits and protecting human health. It is a fact that the presence of VOCs in indoor air is directly related to health risks [6]. VOCs have adverse health effects on the human body and especially children; being a sensitive group since they do not have completed physical and cognitive development. The systems targeted by VOCs can vary, depending on acute short-term or chronic long-term exposure. The central nervous system and respiratory system are the target systems in acute exposure, causing eye, nose, throat, mucous membrane irritation, headaches, and dizziness. On the other hand, chronic exposure to such compounds is more serious, effecting different systems including the immune, hematopoietic, central nervous, and respiratory systems. As a result of this, immunodeficiency modifies blood chemistry and leukemia, slow reaction times, concentration and balance problems, memory loss, peripheral neuropathy, and asthma are negative results of such exposures $[7,8]$. Generally, VOCs are lipid soluble compounds, and they can pass the blood-brain barrier causing neurologically adverse health effects, which are common problems from exposure.

While many new innovative technological developments in wood finishing have created fashionable furniture units, it is a fact that they can also cause significant indoor air pollution. Designers, manufacturers, and consumers are mostly concerned with the 
aesthetics, functionality, cost, and durability criteria of furniture products. It is important that issues should be considered regarding chronic VOC exposure from furniture. World Health Organization (WHO) guidelines describe indoor air quality as an essential determination of a healthy life and people's well-being, and state that the emission of hazardous substances such as VOCs in indoor air causes many health problems. The WHO has published guidelines for implementing the most effective approaches regarding indoor air quality and public health protection [9]. The United States Environmental Protection Agency (EPA) published "A Guide to Indoor Air Quality" that underlined that the risk of polluted indoor air can be more serious than outdoor air [10]. Qualified indoor air quality has been defined as the concentration of harmful substances below a limit by the institution of American heating, refrigerating, and air conditioning engineers [11]. A report entitled "Revision of European Union Ecolabel criteria for furniture products" published in 2017, stated that VOCs emitted from furniture products are a great concern for indoor air quality. In this report a flexible approach was provided to ensure that emissions can be minimized by using low VOC concentrations and coatings, and testing VOC emissions from the final product while avoiding expensive tests [12]. Typical VOCs consist of aldehydes and benzene derivatives such as formaldehyde, toluene, and benzene. Previous studies mainly focused on VOC emission from building materials [13-15], while furniture has rarely been investigated as the VOCs emission mechanisms of whole furniture items depend on their coating and raw materials. Urea formaldehyde resin and paints are still widely used during the manufacture of furniture, causing the emission of formaldehyde and benzene into indoor air [16]. Currently, there is very little or no information on indoor air quality as a function of VOCs from coated furniture units. Therefore, the objective of this study was to present basic information on the levels of VOCs from different parts of furniture and the adverse effects of these compounds, raising awareness from the perspective of public health protection. Some of the health effects of styrene, toluene, p-dichlorobenzene, xylene, ethyl benzene, benzene, and formaldehyde on human and child health was also reviewed, and VOC emission reduction approaches are also discussed.

\section{Methodology}

2.1. Scope

We aimed to review some of the recent studies on the measurement of VOC emissions from different parts of furniture units. The individual VOCs selected were styrene, toluene, p-dichlorobenzene, xylene, ethyl benzene, benzene, and formaldehyde, due to their emission properties from different types of wood-based furniture. Their purpose of use, limit values, and possible adverse health effects are discussed.

The toxicological profile and public health statements for each individual VOC, considering the Agency for Toxic Substances and Disease Registry (ATSDR) and US EPA reports, were also reviewed within the scope of this work.

\subsection{Search Strategy}

The literature search included the following aspects and disciplines: detection aspects of monitoring VOC emission, VOC sampling methods, analytical techniques for monitoring VOC emissions, VOC emissions from different parts of furniture, toxicological profiles and adverse health effects of the selected individual compounds, and the concentrations of individual VOCs. The following electronic databases were investigated: Scopus (including citation reports), Elsevier, Google Scholar, and PubMed. The selected literature were published in English from 1999-2021. The search strategy is summarized in Figure 1. 


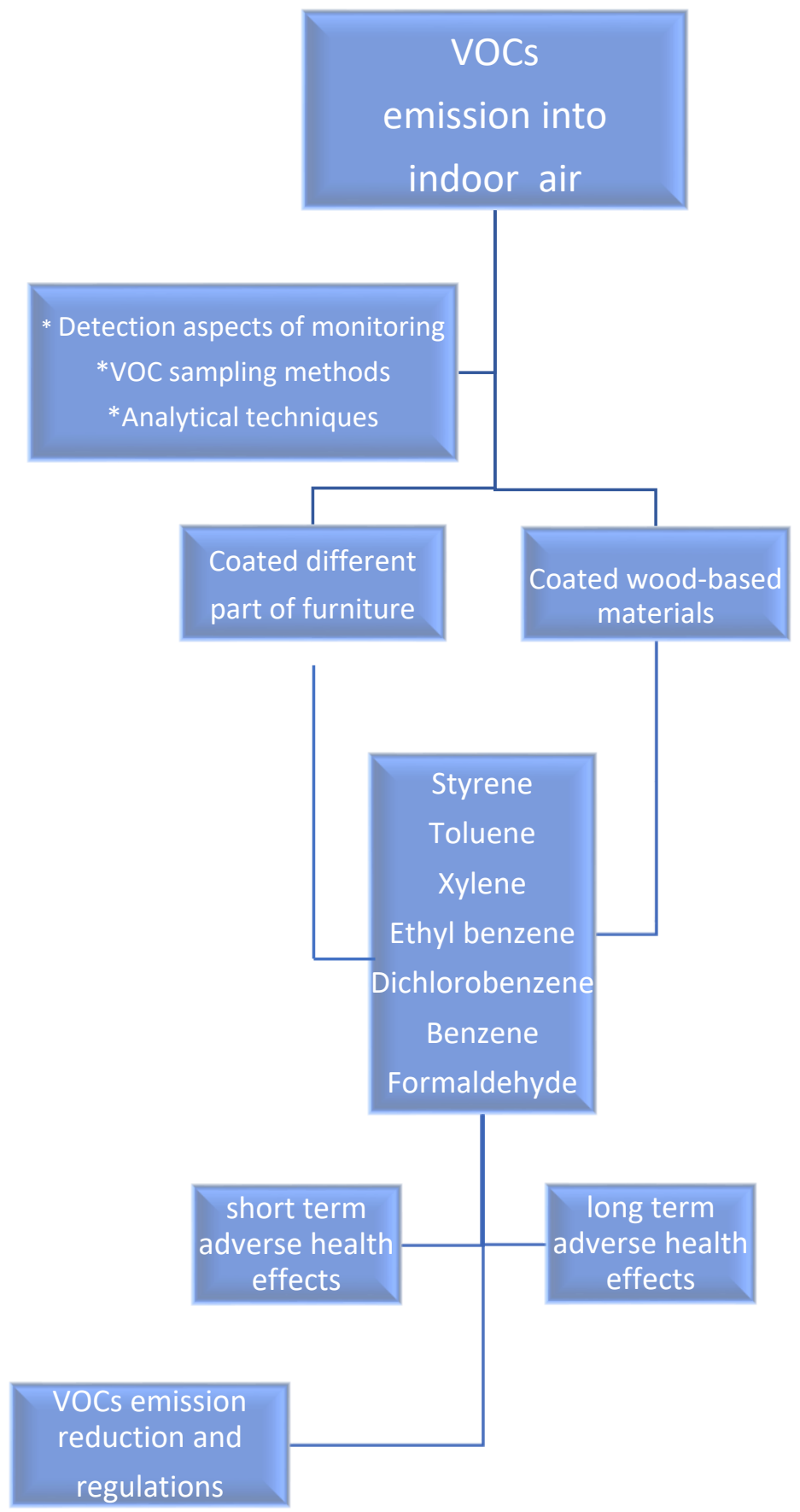

Figure 1. The literature search strategy of the review.

\subsection{Analysis of VOCs}

Emission sources into indoor air include different parts of furniture. VOC emissions from different types of furniture unit were investigated by searching VOC sources such as coatings, adhesives, and extractives individually (Figure 2). The main common ingredients were noted, along with the range of concentrations and regulation limits. After selecting the common VOCs that are emitted from both coated solid wood and wood-based composite furniture units, guideline values of indoor air concentrations and the possible adverse health effects of these chemicals were summarized regarding short-term and long-term exposure. The findings of the included studies were grouped to understand their possible adverse health effects, especially from the point of view of children's health. Furthermore, literature regulations that are helpful for controlling indoor air quality, international and 
national standards, and criteria for furniture in terms of managing VOC emissions were noted in the review. Recent studies about VOC emissions reduction were also investigated and the use of artificial intelligence for predicting VOC emissions was considered as a promising method for detecting VOC emission in indoor air. Recent restrictions, alternative congeners, and detection methods were also analyzed for guiding further studies.

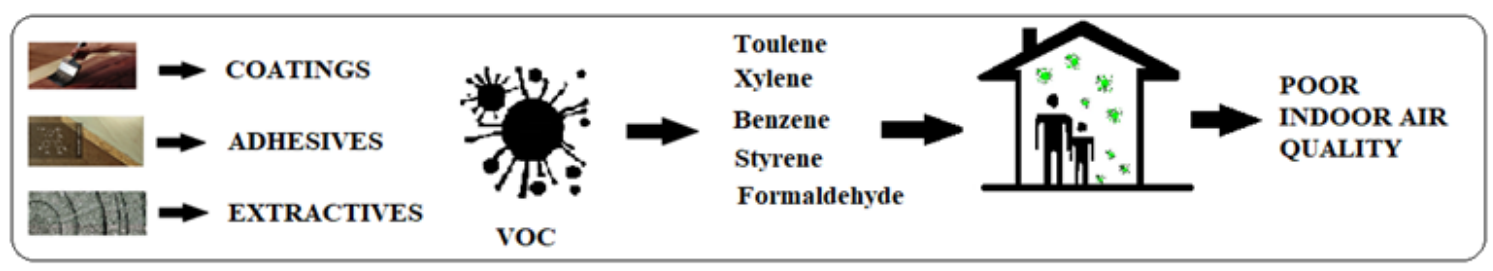

Figure 2. Volatile organic compounds (VOCs) from different types of furniture units.

VOC measurement from indoor air can be assessed with sorption tubes, such as dinitrophenylhydrazine (DNPH) cartridges, Tenax TA sorbent, or air detectors. The VOCs are adsorbed by these materials and then desorbed by elution (DNPH) or thermally (Tenax TA), and eventually analyzed by gas chromatography-mass spectrometry (GC-MS), gas chromatograph - flame ionization detector (GC-FID) or high-performance liquid chromatography (HPLC). Reference gas mixtures are needed for the quality control of these VOC-measurements [17].

The collection of air samples is the first step of VOC monitoring in all techniques, although there are different accepted methods of VOC sampling in the air [18]. Active sampling can be carried out by drawing a specified volume of air through an adsorbent tube at a constant air flow rate using a pump. Sampling can be carried out continuously for long-term use, as well as intermittently at certain time intervals. Grab sampling is generally done for very short periods of time, ranging from 10-30 s and using polished stainless steel or aluminum canisters. However, evacuated canisters can also be used for time integrated sampling from minutes to days using a suitable flow restricted inlet. The collected samples are analyzed in the laboratory to determine the overall concentration levels of the VOCs. Passive sampling, with adsorbents contained in a thin tube, is also widely used to collect samples. The cross section of the tube and the distance between its opening and the adsorbent surface is used to determine the rate of the passive sample [19].

- Gas chromatography (GC) is the most used separation analytical technique for VOCs, where the target compounds are classified inside a column and a liquid stationary phase is adsorbed onto the surface and an inert gaseous phase in a mobile condition. High performance liquid chromatography (HPLC) is also widely used for the separation, identification, and quantification of each component in a mixture. This technique is based on the logic of advancing a pressurized liquid solvent as well as a solid adsorbent at stationary phase at high pressure [20]. Different types of detectors are used.

- $\quad$ Flame ionization detector (FID): The flame ionization detector (FID) is an accepted standard piece of equipment used for measuring hydrocarbon gas concentration. This equipment has mass rather than concentration sensitivity; therefore, it is preferred for general hydrocarbon gas analysis with detection ranges within certain levels of variation [21].

- Thermal conductivity detector (TCD): A TCD is used to also detect water, air, hydrogen, carbon monoxide, nitrogen, sulfur dioxide, and other compounds found in VOCs. Its operating principle depends on the temperature variation of a hot filament when the gas in the unit is diluted. The flow of helium carrier gas as well as the filament temperature are kept at a constant level, while compounds with different thermal conductivities cause heat to be conducted away from the filament, so that the filament temperature and electrical resistance can be measured [22]. 
- Electron capture detector (ECD): An ECD is an ideal method for determining chemicals from pesticides and industrial compounds in the environment [23].

- Flame photometric detector (FPD): A FPD is used based on measurements of the intensity of molecular emission of the fluorescence of hetero atoms in the molecules of organic substances. Low-temperature flames are used for excitation to suitable energy states. The magnitude of the FPD signal is determined by the intensity of the emitted light, based on the chemiluminescence process [24].

- Photo-ionization detector (PID): Ultraviolet light is employed to irradiate the sample in a photoionization detector [21]. The analysis chamber has two plates, where a difference of potential is applied. The intensity of the current is a direct measurement of the number of ionized molecules [25].

Total volatile organic compound (TVOC) emission levels from furniture polishes were investigated, employing a gas chamber method to develop a double exponential model for estimating indoor air quality in a past study [26]. Jiang et al. 2018 also studied the effects of VOCs released by different particleboard panels on indoor air quality [27]. A $1 \mathrm{~m}^{3}$ climate chamber was used for collecting gas samples, which included VOCs from different types of particleboard panels. The climate chamber was based on ISO-16000-9 (2006) and ISO-16000-6 (2011), and the climate chamber parameters were set to the ASTM D 5116 (2010) standard [27]. Cech and Stadnik used a GC/MS device and CSN EN ISO 16000 part 1, 5, and 9 standards for analyzing VOCs [28]. It was reported that veneered particleboard painted with polyurethane lacquer had higher TVOC values than those of other samples.

In another work, Chen et al. (2020) evaluated the effect of surface finishing methods on particleboard volatile organic compounds and formaldehyde emissions by using a GC/MS device. In this study the barrier effect of melamine-impregnated paper of $120 \mathrm{~g} / \mathrm{m}^{2}$ was found to be better than that of melamine-impregnated paper of $80 \mathrm{~g} / \mathrm{m}^{2}$ [29].

Sun et al. (2020) analyzed the effect of the manufacturing conditions on the VOCs emitted from coated particleboard samples using a GC/MS (Trace DSQ II, Thermo Scientific, Waltham, MA, USA) system consisting of a trace gas chromatographic and a DSQ ${ }^{\circ} \mathrm{C}$ mass selective detector [30]. Ho et al. (2011) evaluated the emission rates of volatile organic compounds released from newly produced furniture products using a large-scale chamber testing method. They used a $5 \mathrm{~m}^{3}$ chamber, and the relative ordering of emission rates of the units were assessed in terms of total VOC (TVOC) and arranged as follows: dining table $>$ sofa $>$ desk chair $>$ bedside table $>$ cabinet. The collected sampling tube was analyzed for VOCs by a gas chromatography/mass spectrometer (GC/MS) system combined with a thermal desorber [31].

\section{VOCs Emission from Different Furniture Products and Materials}

Furniture units are mostly manufactured from solid wood and wood-based panels. Their surface is coated with different types of finishes, including lacquers and varnishes, stains, resin impregnated papers, overlays, and high-pressured laminates. The majority of these finishes have terpenes, aromatic hydrocarbons, or aldehydes in their chemical structure and emit different VOCs [32-35] as displayed in Table 1. As a widely used coating material, lacquer can improve the smoothness and gloss, the feel of the surface texture, and the three-dimensional nature, as well as enhancing the natural color wood. Among the lacquer types, waterborne lacquers and polyurethane (PU) lacquers release esters, alcohol compounds, and aromatic hydrocarbons. However ultraviolet (UV)-curable lacquer does not release any esters or other compounds and shows the most inhibitory effect on aldehydes, alcohols, and ketones.

Finishing products such as solvents, emulsions, and aerosol-based chemicals are designed to enhance the overall quality and service life of the final product. In the case of using wood composite panels, including particleboards, medium density fiberboard $(\mathrm{MDF})$, and oriented strand boards (OSB) in the units, some of the coatings, including but 
not limited to overlays, are also used on the surface of the units and they often reduce the VOC emissions from the substrate.

The main common ingredients of solvent- and emulsion-type finishes are toluene, xylene, benzene, and styrene [26]. Ethylbenzene and p-dichlorobenzene are intermediates of styrene and styrene acrylic, and carboxylate styrene-butadiene polymers are also used for coating wood substrates [36]. Some of these chemicals are used as solvent cleaning agents to remove stains on the surface and for preparation for further treatments such as painting or applying conversion coatings in furniture industry [37]. Moisture content is also a well-known key parameter influencing overall coating quality and its service life as a function of species. In a past study, it was found that a lower moisture content of a unit increased VOCs emission such as aldehydes and methanol, whereas a higher moisture content resulted in more terpene emissions [38].

Certain treatment chemicals are also used for wood-based furniture units as a preservative to extend their service life against biological degradation or fire. Propiconazole, tebuconazole, and permethrin are widely used for such a purpose, although they have low emission properties [39]. Flame retardants are commonly used for different types of furniture to hinder fire, and these can be emitted from the units into the air. Polybrominated diphenyl ether congeners have been synthesized as flame retardants, and there are 209 polybrominated diphenyl ethers (PBDEs) compounds called congeners. Three of these are widely used as flame retardants, namely decabromodiphenyl ether (deca-BDE), penta-BDE, and octa-BDE. These three substances and mixtures have not been allowed to be manufactured or sold on the EU market as of March 2019 [40,41].

Table 1. VOC emission characteristics from different furniture units.

\begin{tabular}{|c|c|c|c|c|}
\hline Furniture Unit & Sampling Apparatus & Analyzing Method & Reported VOC & References \\
\hline $\begin{array}{l}\text { Polished wood } \\
\text { products }\end{array}$ & Glass chamber & $\begin{array}{l}\text { Gas } \\
\text { chromatography-mass } \\
\text { spectroscopy (GC-MS) }\end{array}$ & $\begin{array}{l}\text { Toluene, Xylene, } \\
\text { Benzene, Styrene }\end{array}$ & $\begin{array}{l}\text { Guo and Murray, } 2001 \\
\text { [26] }\end{array}$ \\
\hline $\begin{array}{l}\text { Melamine-coated } \\
\text { particleboard, } \\
\text { MDF panels painted } \\
\text { with acrylic finish, } \\
\text { High pressure laminate, } \\
\text { coated particleboard }\end{array}$ & VOC Historical Data & Computer Software & TVOC & Menghi et al., 2018 [42] \\
\hline $\begin{array}{l}\text { Veneered particleboard, } \\
\text { Lacquer finished } \\
\text { particleboard, coatings } \\
\text { of particleboard }\end{array}$ & $\begin{array}{c}1 \mathrm{~m}^{3} \text { sized climate } \\
\text { chamber }\end{array}$ & $\begin{array}{l}\text { Gas } \\
\text { chromatography-mass } \\
\text { spectroscopy (GC-MS) }\end{array}$ & $\begin{array}{l}\text { Buthylacetate, } \\
\text { Hexanal, } \\
\text { Buthylethanol, } \\
\text { TVOC }\end{array}$ & $\begin{array}{l}\text { Čech and Stádník, } 2017 \\
\text { [28] }\end{array}$ \\
\hline $\begin{array}{c}\text { Melamine impregnated } \\
\text { paper, } \\
\text { High density } \\
\text { polyethylene, } \\
\text { Wood veneer, } \\
\text { Water borne painting, } \\
\text { coatings of } \\
\text { particleboard }\end{array}$ & $0.09 \mathrm{~m}^{3}$ sized chamber & $\begin{array}{l}\text { ppbRAE Plus handheld } \\
\text { VOC detector }\end{array}$ & $\begin{array}{l}\text { Phthalic acid, } \\
\text { Toluene, } \\
\text { Furan Ketone, } \\
\text { Ethyl benzene, } \\
\text { Basilene, } \\
\text { Castor acid, }\end{array}$ & Chen et al., 2020 [29] \\
\hline $\begin{array}{l}\text { Polishing, } \\
\text { Varnishing, } \\
\text { Painting, } \\
\text { Particleboard }\end{array}$ & $\begin{array}{l}\text { Portable hand air } \\
\text { sampler, EM-500 }\end{array}$ & $\begin{array}{l}\text { Gas chromatography } \\
\text { (GC) }\end{array}$ & $\begin{array}{c}\text { Benzene, } \\
\text { Toluene, } \\
\text { Xylenes, } \\
\text { Ethlbenzene, } \\
\text { Isopropyl benzene, } \\
\text { Styrene, } \\
\text { n-Hexane }\end{array}$ & Tong et al. 2018 [43] \\
\hline
\end{tabular}


Table 1. Cont.

\begin{tabular}{|c|c|c|c|c|}
\hline Furniture Unit & Sampling Apparatus & Analyzing Method & Reported VOC & References \\
\hline $\begin{array}{l}\text { UF adhesive used } \\
\text { particleboard }\end{array}$ & Tenax-TA tube & $\begin{array}{l}\text { Gas } \\
\text { chromatography-mass } \\
\text { spectroscopy (GC-MS) }\end{array}$ & $\begin{array}{c}\text { Acetic acid, } \\
\text { Butyl ester, } \\
\text { Benzaldehyde, } \\
\text { Ethylbenzene, } \\
\text { Benzyl Alcohol, } \\
\text { Acetophenone, } \\
\text { Tetradecane }\end{array}$ & Sun et al., 2020 [30] \\
\hline $\begin{array}{c}\text { Dining table, } \\
\text { Sofa, } \\
\text { Desk chair, } \\
\text { Bed side table, } \\
\text { Cabinet }\end{array}$ & $\begin{array}{c}5 \mathrm{~m}^{3} \text { sized climate } \\
\text { chamber }\end{array}$ & $\begin{array}{l}\text { Gas } \\
\text { chromatography-mass } \\
\text { spectroscopy (GC-MS) }\end{array}$ & $\begin{array}{c}\text { Butyl ester, } \\
\text { Benzaldehyde, } \\
\text { Ethylbenzene, } \\
\text { Benzyl Alcohol, } \\
\text { Acetophenone } \\
\text { Nonanal, } \\
\text { Decanal, } \\
\text { Heptane, } \\
\text { Styrene }\end{array}$ & Ho et al., 2011 [31]. \\
\hline $\begin{array}{l}\text { Scots pine samples } \\
\text { painted with lacquer } \\
\text { coatings }\end{array}$ & Tenax TA tube & TD/GC/MS analyses & $\begin{array}{c}\text { Butyl ester, } \\
\text { Benzaldehyde, } \\
\text { Ethylbenzene, } \\
\text { Benzyl Alcohol, } \\
\text { Acetophenone } \\
\text { Nonanal, } \\
\text { Decanal, } \\
\text { Heptane, } \\
\text { Limonene, } \\
\text { Styrene }\end{array}$ & Wencek et al. 2015 [44] \\
\hline $\begin{array}{l}\text { PVC-coated, } \\
\text { melamine-coated, } \\
\text { particleboards }\end{array}$ & $\begin{array}{c}1 \mathrm{~m}^{3} \text { sized climate } \\
\text { chamber-Tenax TA } \\
\text { tube }\end{array}$ & $\begin{array}{l}\text { Gas } \\
\text { chromatography-mass } \\
\text { spectroscopy (GC-MS) }\end{array}$ & $\begin{array}{c}\text { Esters, } \\
\text { Aldehydes, } \\
\text { Ketones, } \\
\text { Aromatic } \\
\text { Hydrocarbons }\end{array}$ & Jiang et al., 2018 [27] \\
\hline
\end{tabular}

\section{The Possible Adverse Health Effects of VOCs}

Different chemicals used for the finishing of wood-based furniture have been noted as phthalates, flame retardants, some heavy metals, and VOCs. Phthalate types of plasticizers and flame retardant compounds are emitted from furniture units [45]. In a previous study detailed information about the toxic effects of phthalates and flames retardants was given [41].

In a recent study, dimethyl esters of adipic, glutaric, and succinic acids, namely dimethyl adipate, dimethyl glutarate, and dimethyl succinate emissions from the coatings of some wooden furniture were detected, and it was concluded that they might be emerging indoor air pollutants and need further investigation, since the average airborne concentrations were found to be higher than the $1 \mu \mathrm{g} / \mathrm{m}^{3}$ that was recommended as a limit value for these esters by the Michigan Department of Environmental Quality, United States [46]. Subchronic inhalation toxicity studies have shown that these esters induce a mild degeneration of the olfactory system that affects the sense of smell [47].

Risk characterizations should display the key values of clarity, transparency, reasonableness, and consistency. The final step of a risk assessment is the calculation of the upper-bound excess lifetime cancer risks (risk) and the safe limit values of noncarcinogenic hazards (hazard). Apart from a few exceptions, it is difficult to calculate safe limit values for carcinogenic substances, since the smallest amounts of carcinogens can cause cancer mutations in cells. The slope factor is used in risk assessments to estimate the probability of developing cancer as a result of exposure to a particular level of a potential carcinogen. For example, a risk of $1 \times 10^{-5}$ is interpreted to mean that an individual has a one in 100,000 
chance of developing cancer from the exposure being evaluated. For non-carcinogenic compounds, the first step of the toxicological risk assessment is the dose-result identification, here the type of exposure, as either short-term or long-term, has a key importance. The determination of exposure route is another important step. In terms of VOC exposure, inhalation can be considered as the primary route. Inhalation exposure is related to exposure frequency and duration. The 8-h average VOC concentrations per day in indoor environments can be used for risk assessments. The lowest concentration of interest (LCI) approach is still the most reliable strategy for calculating reference values referring to the potential health effects of individual compounds emitted from raw materials and finished products [48].

On the other hand, there are studies that aimed to measure the VOC concentrations $\left(\mu \mathrm{g} / \mathrm{m}^{3}\right)$ emitted from different furniture types [31,49]. The results of one of these studies indicated that the highest concentration was recorded for toluene $\left(330 \pm 2.51 \mu \mathrm{g} / \mathrm{m}^{3}\right)$ for a sofa, desk chair, bedside table, and cabinet, with the exception of a dining table, in which ethylbenzene was recorded as the highest compound. In another study, the emissions of VOCs from two types of furniture, a bedside table and footstool, were measured at three different loading rates in an environmental chamber. The most dominant VOCs emitted from the bedside table and footstool were found to be styrene and n-undecane, respectively. It was also suggested that furniture may reach high loading rates in indoor environment and could cause a high level of health risk [49]. The adverse effects of VOCs and their limit values [50] are given in Table 2.

Table 2. Allowable values and health effects of VOCs emitted from furniture.

\begin{tabular}{|c|c|c|c|c|}
\hline VOCs & $\begin{array}{l}\text { Limit Values for Indoor } \\
\text { Air } \\
\text { Concentration * }\end{array}$ & $\begin{array}{l}\text { Adverse Health } \\
\text { Effects } \\
\text { Short Term }\end{array}$ & $\begin{array}{l}\text { Adverse Health Effects } \\
\text { Long Term }\end{array}$ & References \\
\hline Styrene & $\begin{array}{l}220 \mu \mathrm{g} / \mathrm{m}^{3} \\
(0.05 \mathrm{ppm})\end{array}$ & $\begin{array}{l}\text { Eyes, nose, and throat } \\
\text { irritation, dermatitis }\end{array}$ & $\begin{array}{l}\text { Neurological effects such as slower } \\
\text { reaction times, hearing problems, } \\
\text { altered hand-eye coordination, } \\
\text { decreased color discrimination, and } \\
\text { impairment of verbal learning skills }\end{array}$ & {$[51]$} \\
\hline Toluene & $260 \mu \mathrm{g} / \mathrm{m}^{3}(0.07 \mathrm{ppm})$ & $\begin{array}{l}\text { Eyes, nose and throat } \\
\text { irritation, dizziness, } \\
\text { headaches }\end{array}$ & $\begin{array}{l}\text { Neurological effects such as reduced } \\
\text { scores in tests of attention, } \\
\text { short-term memory, and } \\
\text { concentration }\end{array}$ & {$[52]$} \\
\hline Xylene & $\begin{array}{l}870 \mu \mathrm{g} / \mathrm{m}^{3} \\
(0.20 \mathrm{ppm})\end{array}$ & $\begin{array}{l}\text { Nose, throat and } \\
\text { lungs irritation }\end{array}$ & $\begin{array}{c}\text { Headache, dizziness, confusion, } \\
\text { liver and kidney damage, heart } \\
\text { problems, and coma }\end{array}$ & [53] \\
\hline Ethyl benzene & $\begin{array}{c}3800 \mu \mathrm{g} / \mathrm{m}^{3} \\
(0.88 \mathrm{ppm})\end{array}$ & $\begin{array}{l}\text { Vertigo and } \\
\text { dizziness }\end{array}$ & $\begin{array}{l}\text { Irreversible damage to the inner ear } \\
\text { and hearing, kidney damage in } \\
\text { animals. It is possibly carcinogenic } \\
\text { to humans }\end{array}$ & {$[54]$} \\
\hline Dichlorobenzene & $\begin{array}{l}240 \mu \mathrm{g} / \mathrm{m}^{3} \\
(0.04 \mathrm{ppm})\end{array}$ & $\begin{array}{l}\text { Skin, throat, and } \\
\text { eye irritation }\end{array}$ & $\begin{array}{l}\text { Liver, skin, and central nervous } \\
\text { system (CNS), such as the cerebellar } \\
\text { ataxia, dysarthria, weakness in } \\
\text { limbs, and hyporeflexia }\end{array}$ & {$[55]$} \\
\hline Benzene & $\begin{array}{l}\text { No safe level of exposure } \\
\text { can be recommended. The } \\
\text { unit risk of leukemia per } \\
1 \mu \mathrm{g} / \mathrm{m}^{3} \text { air concentration } \\
\text { is } 6 \times 10^{-6}\end{array}$ & $\begin{array}{l}\text { Classic symptoms of } \\
\text { CNS depression such } \\
\text { as dizziness, ataxia, } \\
\text { and confusion }\end{array}$ & $\begin{array}{l}\text { Human carcinogen, long-term } \\
\text { exposure linked to acute } \\
\text { myeloid leukemia (AML) in adults } \\
\text { Relative associations have been } \\
\text { detected for leukemia } \\
\text { and different types of lymphoma } \\
\text { in children }\end{array}$ & [56] \\
\hline Formaldehyde & $\begin{array}{l}100 \mu \mathrm{g} / \mathrm{m}^{3} \\
(0.08 \mathrm{ppm})\end{array}$ & $\begin{array}{l}\text { eyes, nose and throat } \\
\text { irritation, sneezing, } \\
\text { lachrymation, } \\
\text { coughing, nausea, and } \\
\text { dyspnea }\end{array}$ & $\begin{array}{l}\text { Human carcinogen, long-term } \\
\text { exposure linked to nasal cancer }\end{array}$ & [57] \\
\hline
\end{tabular}


It appears that the VOCs emitted from furniture units and their possible adverse health effects on adults and children should be taken into consideration, in terms of raising awareness and protecting human health, especially in lockdown conditions. Children are a particularly sensitive group due to their weak immune systems, and they are more vulnerable to such chemicals for the reasons listed below:

- Children's physical and cognitive development is in progress.

- Children have a lower body weight, and they breathe faster than adults, so they are more affected by chemical substances in the air.

- Their metabolizing capacity is slow, so some chemicals stay in their bodies for a longer period.

- Many chemicals can mimic hormones; therefore, they can have a negative effect on the endocrine and developing systems [58].

In a previous study, the exposure of 65 primary school children to toluene, xylenes, ethyl benzene, and benzene was investigated by using organic vapor monitors for $24 \mathrm{~h}$, and all hazard computation values for the non-cancer health effects of these VOCs were found to be larger than 1, based on calculations form the EPA's Risk Assessment Guidance for Superfund (RAGS) part F [59].

\section{VOC Emission Reduction and Suggestions}

It was measured that the possibility of indoor pollution could be 10 times higher than outdoor pollution [60]. It is very important for VOC emissions to be controlled by authorities to protect adult and child health. These regulations are also helpful for the control of indoor odor problems arising from furniture.

There are national and international regulations for the VOC emissions of furniture [61,62]. Overall, the 2010 WHO Indoor Air Quality Guidelines identified the limit values of VOCs for different materials [63]. VOC-free flux is water soluble and serves as a safer alternative tool for furniture. In Europe, the VOC emissions from different products are standardized by the European Committee for Standardization (CEN) and by the International Organization for Standardization (ISO).

Coated particle board and fiber boards are widely used in cabinet manufacture. Formaldehyde emissions and other VOCs are limited by certain criteria, where relevant to the substances used in such composite furniture products. Formaldehyde emissions from particleboard and fiberboard panels are classified as E1 (0.1 ppm) or E2 (0.1-0.3 ppm) based on the EN 13986 standard. Formaldehyde release limits are stated by the EN standards EN 120 and EN 717-1. An allowance for higher formaldehyde emissions for medium density fiberboard (MDF) panels of $65 \%$ of $\mathrm{E} 1$ is permitted due to practical experience with such panel types [64]. In the USA, the American National Standard Institute limits (ANSI/BIFMA-M7.1) VOC levels using a reward system for furniture [48]. By testing to the ISO/IEC 28360 standard, manufacturers can minimize odor complaints and achieve consumer acceptability, demonstrate compliance with industry requirements, bring products to market that support healthier indoor environments, and use the results as a baseline testing for regulatory risk assessment [65].

In the USA, some household products are regulated for VOCs by the EPA under the Clean Air Act (CAA). Sometimes, the Clean Air Act (CAA) causes confusion, as some products that are labeled as "no VOC" or "low VOC" under the CAA can contain volatile organic chemicals having a high level of toxicity. It is important that new regulations and standards protect against the adverse influence of these chemical on human health [66].

Current regulations differ in countries around the world. In Table 3, the limit values of VOC emissions from wood-based furniture are summarized for different countries. 
Table 3. Different regulations in various countries.

\begin{tabular}{|c|c|c|c|}
\hline Regulation-Country & Substances & Limit Values & Reference \\
\hline Germany & $\begin{array}{l}\text { Carcinogenic compounds ( } 3 \text { days) } \\
\text { TVOCs ( } 3 \text { days) } \\
\text { Carcinogenic compounds ( } 28 \text { days) } \\
\text { TVOCs ( } 28 \text { days) }\end{array}$ & $\begin{array}{c}0.01 \mathrm{mg} / \mathrm{m}^{3} \\
10 \mathrm{mg} / \mathrm{m}^{3} \\
0.001 \mathrm{mg} / \mathrm{m}^{3} \\
1 \mathrm{mg} / \mathrm{m}^{3}\end{array}$ & [48] \\
\hline Belgium & $\begin{array}{c}\text { Formaldehyde (28 days) } \\
\text { Acetaldehyde (28 days) } \\
\text { Toluene ( } 28 \text { days) } \\
\text { TVOCs ( } 28 \text { days) } \\
\text { Carcinogen substances }\end{array}$ & $\begin{array}{l}0.1 \mathrm{mg} / \mathrm{m}^{3} \\
0.2 \mathrm{mg} / \mathrm{m}^{3} \\
0.3 \mathrm{mg} / \mathrm{m}^{3} \\
0.1 \mathrm{mg} / \mathrm{m}^{3} \\
0.001 \mathrm{mg} / \mathrm{m}^{3}\end{array}$ & [48] \\
\hline $\begin{array}{c}\text { RAL UZ38 } \\
\text { (Northern Europe) }\end{array}$ & $\begin{array}{l}\text { Formaldehyde } \\
\text { Organic compounds with a boiling point between } 50{ }^{\circ} \mathrm{C} \text { and } 250{ }^{\circ} \mathrm{C} \\
\text { Organic compounds with a boiling point higher than } 250{ }^{\circ} \mathrm{C} \\
\mathrm{CMR} \text { (carcinogenic, mutagenic, reprotoxic) }\end{array}$ & $\begin{array}{l}0.05 \mathrm{ppm} \\
600 \mu \mathrm{g} / \mathrm{m}^{3} \\
100 \mu \mathrm{g} / \mathrm{m}^{3} \\
<1 \mu \mathrm{g} / \mathrm{m}^{3}\end{array}$ & [48] \\
\hline China & $\begin{array}{l}\text { Formaldehyde emission } \\
\text { Benzene } \\
\text { Toluene } \\
\text { Xylene } \\
\text { TVOC }\end{array}$ & $\begin{array}{l}\leq 0.10 \mathrm{mg} / \mathrm{m}^{3} \\
\leq 0.11 \mathrm{mg} / \mathrm{m}^{3} \\
\leq 0.20 \mathrm{mg} / \mathrm{m}^{3} \\
\leq 0.20 \mathrm{mg} / \mathrm{m}^{3} \\
\leq 0.60 \mathrm{mg} / \mathrm{m}^{3}\end{array}$ & [67] \\
\hline $\begin{array}{l}\text { ANSI/BIFMA } \\
\text { X7.1-2011 } \\
\text { (R2016) (US) }\end{array}$ & $\begin{array}{l}\text { TVOC } \\
\text { Formaldehyde } \\
\text { Toluene } \\
\text { Total aldehyde }\end{array}$ & $\begin{array}{l}\leq 0.5 \mathrm{mg} / \mathrm{m}^{3} \\
\leq 50 \mathrm{ppb} \\
\leq 25 \mathrm{ppb} \\
100 \mathrm{ppb}\end{array}$ & [68] \\
\hline
\end{tabular}

Regulations are the primary method for protecting human health. On the other hand, it is also important to develop awareness about increasing ventilation when using products that emit VOCs, as this can also be suggested for decreasing VOC levels in indoor air. It is also recommended to ventilate rooms very often as a primary precaution for reducing VOCs.

It is known that the long-term effects of VOC's can result in serious health problems such as cancer, and respiratory or neurological disorders. As mentioned above, children can be more susceptible and sensitive to these chemical's short-term and long-term effects. There is a great need for overall control of VOCs in indoor environments and having VOC-free green alternatives [69-71].

An artificial neural network (ANN) was also used to predict VOC emissions from furniture units in a past work [72]. Four kinds of furniture were tested in a chamber under different environmental conditions, and the mean absolute percentage error was found to be within $10 \%$ between the predictions and experiments when employing the ANN. It can be also suggested that this ANN model is superior to the traditional physical models for predicting VOC concentrations, since the study showed that ANNs in machine learning are a powerful tool for characterizing furniture emissions [72].

From the point of view of the development of novel coating materials and processes for reducing VOCs emission, recent studies are promising.

VOC emissions from wood materials can be reduced by applying relevant finishing materials. However, according to some researchers, the suggested solution could reduce the emission rate of one chemical, while increasing the emission rate of other chemicals $[73,74]$. VOC emission reductions from birch plywood glued with phenol formaldehyde resins were shown in a study that substituted phenol with bio-oil; however, in this study, increased formaldehyde emissions were recorded, despite a significant decrease of the total emission of VOCs being detected [75]. VOC emission rates can be decreased by applying the appropriate resins and pressing parameters in MDF [76]. New solutions for decreasing formaldehyde emission are a major research interest since formaldehyde is a human carcinogen. Recently, Bekhta et al. showed that the heat application during the drying process can reduce the formaldehyde emissions of plywood [77]. 
There have also been studies that showed the effects of photocatalytic purification, such as with $\mathrm{TiO}_{2}$ and $\mathrm{Fe} / \mathrm{N}$ co-doped $\mathrm{TiO}_{2}$, on indoor formaldehyde removal efficiency [78].

Another study showed significantly lower emissions of VOCs from lacquer coated wood products containing inorganic metal nanoparticles such as $\mathrm{TiO}_{2}, \mathrm{SiO}_{2}$, and $\mathrm{Ag}$ [44]. It was also shown that the VOC emissions from wood-based materials can be decreased by up to $90 \%$ through the application of marketed coatings [79]. The latex paint test results showed a maximum barrier effect for formaldehyde, whereas a minor barrier effect for acetaldehyde was recorded $[80,81]$.

The study conducted by Pibiri et al. used EN 717-1 and EN 16516 for emission testing, and it was concluded that the results for uncoated wood-based material did not reflect the real behavior in indoor environments under living conditions. When a woodbased material surface was completely coated, the barrier effect could amount to $75 \%$ or more $[64,79,82]$.

In terms of processes, a hybrid strategy was suggested by Landry and coworkers [83] to reduce VOC emissions by considering the high molecular weight solvents associated with water-borne systems and that they may be more stable than solvent-borne systems.

Water based coating techniques, such as water-based varnish and film-forming materials, use water as the dispersion solvent [84]. Compared with the traditional solvent-borne paint, waterborne coatings could eliminate more than $80 \%$ of VOCs and other harmful substances (formaldehyde, benzene, and xylene) in the coating $[85,86]$.

In a recent study conducted by Salca et al., alternative ecological products, including water based and UV varnishes, that are widely used due to their low emissions, rapid application, and good gloss retention were investigated, and it was concluded that the UV varnish coated samples exhibited higher gloss values than the water-borne products. [87].

Another approach for reducing VOC emissions is a powder coating that contains no solvents, and which is usually applied in the form of an electrostatic spray gun coating or fluidized bed coating [88]. Powder coating without the emission of VOCs is a clean process, and as such, has attracted increased attention due to its stricter compliance with environmental regulations and superior performance compared to liquid coatings [89]. Owing to the environmental and economic advantages and excellent coating properties offered by powder coatings, their use is not limited to metal surfaces, and has expanded to include wooden furniture, plastics, and paper $[88,90]$.

\section{Conclusions}

Coated furniture units contain different VOCs, influencing the overall quality of indoor air. Indoor VOC pollution can create certain health problems. Many countries have environmental policies for a comfortable, healthy, and green indoor environment. This study presented a summary of the VOCs emitted from different products from the perspective of their adverse health effects. Determining the VOC substances emitted and the emission levels for different type materials and developing standard methods and techniques for detecting VOC emissions, are critical to control their impact on human health. Therefore, this study also covered and reviewed the results of some previous investigations that determined VOC emissions from different types of furniture unit. The recent studies that aimed to reduce VOC emissions from coated wood-based furniture were also reviewed, being promising approaches in terms of improving indoor air quality and protecting human health. One of these approaches, waterborne coating, still needs to overcome many problems [91-93]. Another environmentally and economically advantageous approach that has become popular in recent years is power coating; however, the limited electrical conductivity of the surface has been described as the main difficulty for wood powder coatings. [94,95]. On the other hand, these promising approaches are very important and should be improved and considered as relevant materials for their VOC-free, environmentally friendly, and sustainable properties. 
It is also vital that VOC emissions are controlled by the authorities. It is expected that such regulations will play a significant role in the control of odor problems and in the indoor air quality associated with coated furniture. In conclusion, regarding the adverse health effects of VOC emissions from coated wood-based materials, promising coating approaches and regulations by the authorities will play a critical role in terms of improving indoor air quality and protecting public health.

Author Contributions: Conceptualization, O.C.U. and O.U.; methodology, S.H.; software, O.U.; validation, S.H., O.C.U. and O.U.; formal analysis, O.C.U.; investigation, O.C.U.; resources, O.U.; data curation, S.H.; writing—original draft preparation, O.C.U.; writing—review and editing, O.U.; visualization, O.U.; supervision, S.H.; project administration, O.C.U.; funding acquisition, S.H. All authors have read and agreed to the published version of the manuscript.

Funding: This research received no external funding.

Institutional Review Board Statement: Not applicable.

Informed Consent Statement: Not applicable.

Data Availability Statement: Data is contained within the article.

Conflicts of Interest: The authors declare no conflict of interest.

\section{References}

1. Missia, D.A.; Demetriou, E.; Michael, N.; Tolis, E.I.; Bartzis, J.G. Indoor exposure from building materials: A field study. Atmos. Environ. 2010, 44, 4388-4395. [CrossRef]

2. Bartzis, J.; Wolkoff, P.; Stranger, M.; Efthimiou, G.; Tolis, E.I.; Maes, F.; Nørgaard, A.W.; Ventura, G.; Kalimeri, K.K.; Goelen, E.; et al. On organic emissions testing from indoor consumer products' use. J. Hazard. Mater. 2015, 285, 37-45. [CrossRef] [PubMed]

3. Cacho, C.; Ventura Silva, G.; Martins, A.O.; Fernandes, E.O.; Saraga, D.E.; Dimitroulopoulou, C.; Bartzis, J.G.; Rembges, D.; Barrero-Moreno, J.; Kotzias, D. Air pollutants in office environments and emissions from electronic equipment: A review. Fresenius Environ. Bull. 2013, 22, 2488-2497.

4. Nandan, A.; Siddiqui, N.A.; Kumar, P. Estimation of indoor air pollutant during photocopy/printing operation: A computational fluid dynamics (CFD)-based study. Environ. Geochem. Health 2020, 42, 3543-3573. [CrossRef] [PubMed]

5. Wang, Q.; Shen, J.; Cao, T.; Du, J.; Dong, H.; Shen, X. Emission Characteristics and Health Risks of Volatile Organic Compounds and Odor from PVC-overlaid Particleboard. BioResources 2019, 14, 4385-4402.

6. Sarigiannis, D.A.; Karakitsios, S.P.; Gotti, A.; Liakos, I.L.; Katsoyiannis, A. Exposure to major volatile organic compounds and carbonyls in European indoor environments and associated health risk. Environ. Int. 2011, 37, 743-765. [CrossRef] [PubMed]

7. Li, A.J.; Pal, V.K.; Kannan, K. A review of environmental occurrence, toxicity, biotransformation and biomonitoring of volatile organic compounds. Environ. Chem. Ecotoxicol. 2021, 3, 91-116. [CrossRef]

8. Dallinga, J.W.; Robroeks, C.M.H.H.T.; Van Berkel, J.J.B.N.; Moonen, E.J.C.; Godschalk, R.W.L.; Jöbsis, Q.; Van Schooten, F.J. Volatile organic compounds in exhaled breath as a diagnostic tool for asthma in children. Clin. Exp. Allergy 2010, 40, 68-76. [PubMed]

9. Heseltine, E.; Rosen, J. (Eds.) WHO Guidelines for Indoor Air Quality: Dampness and Mould; WHO: Geneva, Switzerland, 2009.

10. Publications about Indoor Air Quality. Available online: http:/ / epa.gov/indoor-air-quality-iaq/publications-about-indoor-airquality (accessed on 1 February 2021).

11. Seguel, J.M.; Merrill, R.; Seguel, D.; Campagna, A.C. Indoor air quality. Am. J. Lifestyle Med. 2017, 11, 284-295. [CrossRef]

12. Donatello, S.; Moons, H.; Wolf, O.; Revision of EU Ecolabel Criteria for Furniture Products. European Commission. Available online: http:/ / ec.europa.eu/environment/ecolabel/documents/technical_report_furniture.pdf (accessed on 1 February 2021).

13. Liu, Z.; Ye, W.; Little, J.C. Predicting emissions of volatile and semivolatile organic compounds from building materials: A review Build. Environ. 2013, 64, 7-25. [CrossRef]

14. Zhang, Y.P.; Xiong, J.Y.; Mo, J.H.; Gong, M.Y.; Cao, J.P. Understanding and controlling airborne organic compounds in the indoor environment: Mass-transfer analysis and applications. Indoor Air 2016, 26, 39-60. [CrossRef]

15. He, Z.C.; Xiong, J.Y.; Kumagai, K.; Chen, W.H. An improved mechanism-based model for predicting the long-term formaldehyde emissions from composite wood products with exposed edges and seams Environ. Int. 2019, 132, 105086. [CrossRef] [PubMed]

16. Wang, Y.; Wang, H.; Tan, Y.; Liu, J.; Wang, K.; Ji, W.; Sun, L.; Yu, X.; Zhao, J.; Xu, B.; et al. Measurement of the key parameters of VOC emissions from wooden furniture, and the impact of temperature. Atmos. Environ. 2021, 259, 118510. [CrossRef]

17. DIN ISO 16000-6. Indoor Air-Part 6: Determination of Volatile Organic Compounds in Indoor and Test Chamber Air by Active Sampling on Tenax TA Sorbent, Thermal Desorption and Gas Chromatography Using MS/FID; German version ISO 16000-6:2011; Beuth Verlag: Berlin, Germany, 2012.

18. Demeestere, K.; Dewulf, J.; De Witte, B.; Van Langenhove, H. Sample preparation for the analysis of volatile organic compounds in air and water matrices. J. Chromatogr. A 2007, 1153, 130-144. [CrossRef] 
19. Srivastava, A.; Dipanjali, M. Monitoring and reporting VOCs in ambient air. In Air Quality Monitoring, Assessment and Management; Intechopen: London, UK, 2011. [CrossRef]

20. Gritti, F.; Guiochon, G. The van Deemter equation: Assumptions, limits, and adjustment to modern high performance liquid chromatography. J. Chromatogr. A 2013, 1302, 1-13. [CrossRef] [PubMed]

21. Chaulya, S.K.; Prasad, G.M. Sensing and Monitoring Technologies for Mines and Hazardous Areas; Monitoring and Prediction Technologies; Elsevier: Amsterdam, The Netherlands, 2016.

22. Uchiyama, S.; Hayashida, H.; Izu, R.; Inaba, Y.; Nakagome, H.; Kunugita, N. Determination of nicotine, tar, volatile organic compounds and carbonyls in mainstream cigarette smoke using a glass filter and a sorbent cartridge followed by the twophase/one-pot elution method with carbon disulfide and methanol. J. Chromatogr. A 2015, 1426, 48-55. [CrossRef] [PubMed]

23. Poole, C.F. Encyclopedia of Analytical Science, 2nd ed.; Elsevier: Amsterdam, The Netherlands, 2005.

24. Azzouz, I.; Khan, M.S.; Bishop, A.C.; Bachari, K. Recent Advances in Targeting Clinical Volatile Organic Compounds (VOC). In Recent Advances in Gas Chromatography; Intechopen: London, UK, 2021. [CrossRef]

25. Stauffer, E.; Dolan, J.A.; Newman, R. Fire Debris Analysis; Academic Press: Cambridge, MA, USA, 2007.

26. Guo, H.; Murray, F. Determination of total volatile organic compound emissions from furniture polishes. Clean Prod. Process. 2001, 3, 42-48. [CrossRef]

27. Jiang, L.; Shen, J.; Li, H.; Wang, Q.; Shen, X. Effects of volatile organic compounds released by different decorative particleboards on indoor air quality. BioRes 2018, 13, 7595-7605. [CrossRef]

28. Cech, P.; Stadnik, J. Materials used for furniture production like source VOC emissions. Ileri Teknoloji Bilimleri Dergisi 2017, 6, 1264-1276.

29. Chen, F.; Shen, J.; Xia, X. Effect of the Surface Finishing Methods on Particleboard Volatile Organic Compounds and Formaldehyde Emission. BioResources 2020, 15, 5450-5463. [CrossRef]

30. Sun, S.; Zhao, Z.; Shen, J. Effects of the manufacturing conditions on the VOCs emissions of particleboard. BioResources 2020, 15, 1074-1084. [CrossRef]

31. Ho, D.X.; Kim, K.H.; Ryeul Sohn, J.; Hee Oh, Y.; Ahn, J.W. Emission rates of volatile organic compounds released from newly produced household furniture products using a large-scale chamber testing method. Sci. World J. 2011, 11, 1597-1622. [CrossRef] [PubMed]

32. Chang, J.C.S.; Guo, Z. Characterization of organic emissions from a wood finishing product-Wood stain. Indoor Air 1992, 2, 146-153. [CrossRef]

33. Järnström, H.; Saarela, K.; Kalliokoski, P.; Pasanen, A.-L. Reference values for indoor air pollutant concentrations in new, residential buildings in Finland. Atmos. Environ. 2006, 40, 7178-7191. [CrossRef]

34. Järnström, H.; Saarela, K.; Kalliokoski, P.; Pasanen, A.L. The impact of emissions from structures on indoor air concentrations in newly finished buildings—-predicted and on-site measured levels. Indoor Built Environ. 2008, 17, 313-323. [CrossRef]

35. He, Z.; Zhang, Y.; Wei, W. Formaldehyde and VOC emissions at different manufacturing stages of wood-based panels. Build. Environ. 2012, 47, 197-204. [CrossRef]

36. Alimardani, M.; Abbassi-Sourki, F. New and emerging applications of carboxylated styrene butadiene rubber latex in polymer composites and blends: Review from structure to future prospective. J. Compos. Mater. 2015, 49, 1267-1282. [CrossRef]

37. Baghdady, Y.Z.; Schug, K.A. A novel diagnostic in situ derivatization kit for the simultaneous determination of 14 biomarkers of exposure to benzene, toluene, ethyl benzene and xylenes in human urine by isotope dilution liquid chromatography tandem mass spectrometry and kit optimization using response surface methodology. Anal. Chim. Acta 2018, 1036, 195-203. [PubMed]

38. Alapieti, T.; Castagnoli, E.; Salo, L.; Mikkola, R.; Pasanen, P.; Salonen, H. The effects of paints and moisture content on the indoor air emissions from pinewood (Pinus sylvestris) boards. Indoor Air 2021. [CrossRef] [PubMed]

39. Schoknecht, U.; Drescher, P.; Fischer, M.; Fürhapper, C.; Gunschera, J.; Hill, R.; Melcher, E.; Wegner, R.; Wilken, U.; Wittenzellner, J. Suitability of analytical methods to determine tebuconazole, propiconazole and permethrin in aged wood samples. Eur. J. Wood Wood Prod. 2020, 78, 271-279. [CrossRef]

40. European Commission (EC). Commission Regulation No of 2017/227 of Amending Annex XVII to Regulation (EC) No 1907/2006 of the European Parliament and of the Council concerning the Registration, Evaluation, Authorization and Restriction of Chemicals (REACH) as Regards Bis(pentabromophenyl)ether; Regulation 2017/227; European Commission: Bruxelles, Belgium, 2017.

41. Ulker, O.C.; Ulker, O. Toxicity of formaldehyde, polybrominated diphenyl ethers (PBDEs) and phthalates in engineered wood products (EWPs) from the perspective of the green approach to materials: A review. BioResources 2019, 14, 7465-7493.

42. Menghi, R.; Ceccacci, S.; Papetti, A.; Marconi, M.; Germani, M. A method to estimate the total VOC emission of furniture products. Procedia Manuf. 2018, 21, 486-493. [CrossRef]

43. Tong, R.; Lei, Z.; Xiaoyi, Y.; Jiefeng, L.; Peining, Z.; Jianfeng, L. Emission characteristics and probabilistic health risk of volatile organic compounds from solvents in wooden furniture manufacturing. J. Clean. Prod. 2019, 208, 1096-1108. [CrossRef]

44. Wencek, A.S.; Zborowska, M.; Pradzynski, W.; Waliszewska, B. Emissions of volatile organic compounds from lacquer coatings used in the furniture industry, modified with nanoparticles of inorganic metal compounds. Turk. J. Agric. For. 2015, 39, 251-259. [CrossRef]

45. Liu, Z.; Little, J.C. Semivolatile organic compounds (SVOCs): Phthalates and flame retardants. In Toxicity of Building Materials; Woodhead Publishing: Southston, UK, 2012; pp. 122-137. 
46. Qiu, J.; Xie, D.; Li, Y.; Qu, Y.; Liu, Y.; Zhu, T.; Liu, Y. Dibasic Esters Observed as Potential Emerging Indoor Air Pollutants in New Apartments in Beijing, China. Environ. Sci. Technol. Lett. 2021, 8, 445-450. [CrossRef]

47. National Center for Biotechnology Information. PubChem Compound Summary for CID 7820, Dimethyl Succinate. Available online: https:/ / pubchem.ncbi.nlm.nih.gov/compound/Dimethyl-succinate (accessed on 1 June 2021).

48. Bulian, F.; Fragassa, C. VOC emissions from wood products and furniture: A survey about legislation, standards and measures referred to different materials. FME Trans. 2016, 44, 358-364. [CrossRef]

49. Yan, M.; Zhai, Y.; Shi, P.; Hu, Y.; Yang, H.; Zhao, H. Emission of volatile organic compounds from new furniture products and its impact on human health. Hum. Ecol. Risk Assess. Int. J. 2019, 25, 1886-1906. [CrossRef]

50. Japanese Ministry of Health Labour and Welfare. Committee on Sick House Syndrome: Indoor Air Pollution, Progress Report no. 3; Office of Chemical Safety, Pharmaceutical and Food Safety Bureau: Tokyo, Japan, 2001. Available online: http:/ / www.nihs.go.jp/ mhlw/chemical/situnai/kentoukai/rep-eng3.pdf (accessed on 21 February 2021).

51. Public Health Statement Styrene. Available online: https://www.atsdr.cdc.gov/ToxProfiles/tp53-c1-b.pdf (accessed on 21 February 2021).

52. Public Health Statement Toluene. Available online: https://www.atsdr.cdc.gov/toxprofiles/tp56-c1-b.pdf (accessed on 21 February 2021).

53. Toxicological Profile for Xylene. Available online: https:/ /www.atsdr.cdc.gov/toxprofiles/tp71.pdf (accessed on 21 February 2021).

54. Toxicological Profile for Ethylbenzene. Available online: https://www.atsdr.cdc.gov/toxprofiles/tp110-c6.pdf (accessed on 21 February 2021).

55. Toxicological Profile for Dichlorobenzene. Available online: https://www.atsdr.cdc.gov/toxprofiles/tp10.pdf (accessed on 21 February 2021).

56. Toxicological Profile for Benzene. Available online: https://www.atsdr.cdc.gov/toxprofiles/tp3.pdf (accessed on 21 February 2021).

57. Toxicological Profile for Formaldehyde. Available online: https://www.atsdr.cdc.gov/toxprofiles/tp111.pdf (accessed on 21 February 2021).

58. Landrigan, P.J.; Goldman, L.R. Children's vulnerability to toxic chemicals: A challenge and opportunity to strengthen health and environmental policy. Health Aff. 2011, 30, 842-850. [CrossRef] [PubMed]

59. Demirel, G.; Özden, Ö.; Döğeroğlu, T.; Gaga, E.O. Personal exposure of primary school children to BTEX, $\mathrm{NO}_{2}$ and ozone in Eskişehir, Turkey: Relationship with indoor/outdoor concentrations and risk assessment. Sci. Total Environ. 2014, 473, 537-548. [CrossRef]

60. Zhang, J.F.; Smith, K.R. Indoor air pollution: A global health concern. Br. Med. Bull. 2003, 68, 209-225. [CrossRef]

61. Revision of EU Ecolabel Criteria for Furniture Products. Available online: https://ec.europa.eu/environment/ecolabel/ documents/technical_report_furniture.pdf (accessed on 2 March 2021).

62. The Inside Story: A Guide to Indoor Air Quality. Available online: https://www.epa.gov/indoor-air-quality-iaq/inside-storyguide-indoor-air-quality (accessed on 2 March 2021).

63. World Health Organization. WHO Guidelines for Indoor Air Quality: Selected Pollutants; WHO: Geneva, Switzerland, 2010.

64. CEN-EN 717-1. Wood-Based Panels-Determination of Formaldehyde Release-Part 1: Formaldehyde Emission by the Chamber Method. Available online: https:/ / standards.globalspec.com/std/808118/EN\%20717-1 (accessed on 2 March 2021).

65. ISO 16000-30:2014(en) Indoor Air-Part 30: Sensory Testing of Indoor Air. Available online: https://www.iso.org/obp/ui/\#iso: std:iso:16000:-30:ed-1:v1:en (accessed on 2 March 2021).

66. Does EPA Regulate Volatile Organic Compounds (VOCs) in Household Products? Available online: https: / www.epa.gov / indoor-air-quality-iaq/does-epa-regulate-volatile-organic-compounds-vocs-household-products (accessed on 2 March 2021).

67. Limits on the Level of Volatile Organic Compounds and the Migration of Heavy Metals in Wooden Furniture. Available online: http:/ / www.puntofocal.gov.ar/notific_otros_miembros/chn1094s1_t.pdf (accessed on 20 June 2021).

68. ANSI/BIFMA X7.1-2011(R2016) Standard for Formaldehyde \& TVOC Emissions of Low-Emitting Office Furniture and Seating, BIFMA, MI, USA. 2011.

69. Fan, L.; Wei, L.; Zhu, Y.; Wang, Y.; Fei, J.; Li, Y. Synthesis of Environmentally Friendly Acrylonitrile Butadiene Styrene Resin with Low VOC. Materials 2020, 13, 1663. [CrossRef] [PubMed]

70. Adamová, T.; Hradecký, J.; Prajer, M. VOC Emissions from Spruce Strands and Hemp Shive: In Search for a Low Emission Raw Material for Bio-Based Construction Materials. Materials 2019, 12, 2026. [CrossRef] [PubMed]

71. Ulker, O.; Hiziroglu, S. Some Properties of Eastern Red Cedar (Juniperus Virginiana L.) Particleboard Panels Made Using Modified Starch as Binder. Drona İndustrija Znanstveni Časopis za Pitanja Drvne Tehnologije 2020, 71, 371-377.

72. Zhang, R.; Wang, H.; Tan, Y.; Zhang, M.; Zhang, X.; Wang, K.; Ji, W.; Sun, L.; Zhao, J.; Xu, B.; et al. Using a machine learning approach to predict the emission characteristics of VOCs from furniture. Build. Environ. 2021, 196, 107786. [CrossRef]

73. Liu, Y.; Zhu, X. Measurement of formaldehyde and VOCs emissions from wood-based panels with nanomaterial-added melamineimpregnated paper. Constr. Build. Mater. 2014, 66, 132-137. [CrossRef]

74. Cao, T.; Shen, J.; Wang, Q.; Li, H.; Xu, C.; Dong, H. Characteristics of VOCs released from plywood in airtight environments. Forests 2019, 10, 709. [CrossRef]

75. Jia, L.; Chu, J.; Li, J.; Ren, J.; Huang, P.; Li, D. Formaldehyde and VOC emissions from plywood panels bonded with bio-oil phenolic resins. Environ. Pollut. 2020, 264, 114819. [CrossRef] 
76. Korenberg, C.; Bertolotti, G. Emissions from MDF: Governing Factors and Mitigation Strategies. Stud. Conserv. 2019, 64, 249-260. [CrossRef]

77. Bektha, P.; Sedliačik, J.; Bekhta, N. Effect of veneer-drying temperature on selected properties and formaldehyde emission of birch plywood. Polymers 2020, 12, 593.

78. Zhang, T.; Li, X.; Rao, Y.; Liu, Y.; Zhao, Q. Removal of formaldehyde in urban office building by the integration of ventilation and photocatalyst-coated window. Sustain. Cities Soc. 2020, 55, 102050. [CrossRef]

79. Pibiri, E.; Omelan, A.; Uhde, E.; Salthammer, T. Effect of surface covering on the release of formaldehyde, acetaldehyde, formic acid and acetic acid from particleboard. Build. Environ. 2020, 178, 106947. [CrossRef]

80. Xiao, X.; Deng, B.; Zhang, P.; Zang, Y.; Zhu, M.; Liang, H. The influence of thickness of Nitrocellulose wood lacquer on Formaldehyde emission rates. Adv. Mater. Res. 2012, 354-355, 231-235. [CrossRef]

81. Tan, Y.; Zhi, Y.; Gao, M.; Cheng, Z.; Yan, B.; Nie, L.; Chen, G.; Hou, L.A. Influence of temperature on formaldehyde emission parameters of solvent-based coatings. J. Coat. Technol. Res. 2021, 18, 677-684. [CrossRef]

82. EN 16516 Construction Products-Assessment of Release of Dangerous Substances-Determination of Emissions into Indoor Air; Beuth Verlag: Berlin, Germany, 2017.

83. Landry, V.; Blanchet, P.; Vaillancourt, É. Reducing VOC emissions in the furniture and cabinets industries: An opportunity for hybrid coating systems. BioResources 2010, 5, 770-779.

84. Yan, X.; Qian, X.; Bao, W. Effect of glass fiber powder on the properties of the waterborne coatings with color changing ink on the Chinese fir surface. China For. Sci. Technol. 2020, 5, 169-174.

85. Lin, X.; Su, J.; Zhang, X.; Tan, Z.; Wang, C.; Wei, S. Synthesis of UV cured waterborne polyacrylate wood coatings modified by silica sol. China For. Sci. Technol. 2019, 4, 170-176.

86. Pánek, M.; Dvořák, O.; Oberhofnerová, E.; Šimůnková, K.; Zeidler, A. Effectiveness of two different hydrophobic topcoats for increasing of durability of exterior coating systems on oak wood. Coatings 2019, 9, 280. [CrossRef]

87. Salca, E.A.; Krystofiak, T.; Lis, B.; Hiziroglu, S. Glossiness Evaluation of Coated Wood Surfaces as Function of Varnish Type and Exposure to Different Conditions. Coatings 2021, 11, 558. [CrossRef]

88. Yu, H.J.; Wang, L.; Shi, Q.; Jiang, G.H.; Zhao, Z.R.; Dong, X.C. Study on nano-CaCO3 modified epoxy powder coatings. Prog. Org. Coat. 2006, 55, 296-300. [CrossRef]

89. Fu, J.; Krantz, M.; Zhang, H.; Zhu, J.; Kuo, H.; Wang, Y.M.; Lis, K. Investigation of the recyclability of powder coatings. Powder Technol. 2011, 211, 38-45. [CrossRef]

90. Akkuş, M.; Akbulut, T.; Candan, Z. Formaldehyde emission, combustion behavior, and artificial weathering characteristics of electrostatic powder coated wood composite panels. Wood Mater. Sci. Eng. 2021, 1-11. [CrossRef]

91. Spilman, G.E.; Moore, S.; Marshall, S.J. Sustainable, low-emissions, highperformance polyols for wood floor coatings. CoatingsTech 2018, 15, 34-43.

92. Cai, Z.; Zhu, H.; Wang, P.; Wu, C.; Gao, W.; Mu, J.; Wei, S. Performance optimization of UV curable waterborne polyurethane acrylate wood coatings modified by castor oil. China For. Sci. Technol. 2020, 5, 89-95.

93. Yan, X.; Wang, L.; Qian, X. Influence of the PVC of glass fiber powder on the properties of a thermochromic waterborne coating for Chinese fir boards. Coatings 2020, 10, 588. [CrossRef]

94. Badila, M.; Jocham, C.; Zhang, W.; Schmidt, T.; Wuzella, G.; Müller, U.; Kandelbauer, A. Powder coating of veneered particle board surfaces by hot pressing. Prog. Org. Coat. 2014, 77, 1547-1553. [CrossRef]

95. Köhler, R.; Sauerbier, P.; Militz, H.; Viöl, W. Atmospheric pressure plasma coating of wood and MDF with polyester powder. Coatings 2017, 7, 171. [CrossRef] 